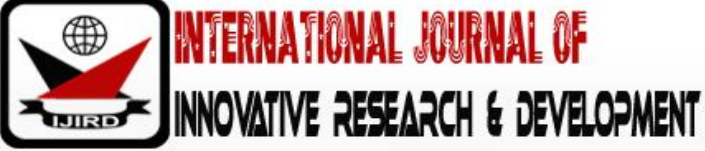

ISSN 2278 - 0211 (Online)

\section{The Impact of Dividend Policy on Share Price Volatility: Empirical Evidence with Colombo Stock Exchange in Sri Lanka}

\author{
DDK Sugathadasa \\ Lecturer, Department of Accountancy \&amp, Finance, Rajarata University of Sri Lanka, Sri Lanka
}

\begin{abstract}
:
Dividend policy comprises the decisions, whether to retain earnings for capital investment and other purposes orto distribute earnings as dividend among shareholders. In advance effect on market prices deemed to be a main determinant of dividend policy. On that concern, the main purpose of this study would be to examine the relationship between dividend policy and share price volatility in Sri Lankan context. Dividend payout ratio and dividend yield deliberated as independent variables after controlling with growth in assets, firm size and debt while share price volatility considered as a proxy of dependent variable. Data were collected through annual reports of 30 selected companies listed in Colombo Stock Exchange for fouryear time period from 2014 to 2017 according to the market capitalization on the date of 31st December 2017. Descriptive analysis and correlation analysis were used to perform the data analysis while regression model was expanded by adding control variables. While confirming the empirical results; findings of this study showed a negative insignificant relationship between dividend yields with share price volatility. Moreover, price volatility has negative correlation with firm size and positive correlation with growth in assets and debt. Based on the findings of this study, dividend payout ratio and dividend yield have negative impact on share price volatility.
\end{abstract}

Keywords: Dividend payout ratio, dividend yield, share price volatility

\section{Introduction}

The unit of ownership of a company is usually identified as a share which representing company's capital structure. The value of a share is determined through demand and supply forces which a share is exchanged in the market. For instance, the share values are not always constant and that variance is identified as price volatility which means changing the values of securities within a given time period. Conversely the volatility of share price deemed to be systematic risk for investors who invested in ordinary shares (Guo, 2002). Usually investors are in the nature of risk aversion on investing activities. Thus, the volatility of price is more important for risk averse investors on making investment decisions appropriately.

According to the agency theory, the ultimate goal of a manager would be to maximize the owner's wealth of a firm. Besides that, corporate finance theory elaborates that there are three major management decisions to be executed by finance manager namely financing decision, investment decision and dividend decision (Ilaboya and Aggreh 2013). When achieving the ultimate goal, dividend decision plays a major role which supports for other two decisions and determine the share price of the firm to demonstrate the firm performances. Dividend decisions are the dividend policy of a firm. The dividend policy refers to a company's policy which determines the amount of dividend payments and the amounts of retained earnings for reinvesting in new projects. However, in current corporate finance aspects, dividend policy involves in wide arena like how to attract investors, how to increase the market value of firm, and share repurchase instead of cash dividends. It may be caused some conflicts in between firm management and owners termed agency problem and maintaining proper dividend policy would be remedy for this conflict. Dividend yield and dividend payout ratio found to be the main factors that affect to the dividend policy and this study is conducting to find out the impact of dividend policy on share price volatility.

A company that does not pay dividends is more attractive to investors than a company that gives dividends (Zakaria, 2012). Therefore, investors preferred to invest in non-dividend paying firms than the dividend paying firms as they believe that there will be an opportunity to increase stock prices in non-dividend paying firms in the future. Therefore, it is important to investigate the impact of dividend decision on share prices volatility which contributes to management decisions and help to achieve organization goals. Meanwhile irrelevance theory (Modigliani and Miller, 1961) cited that dividend policy does not impact on the share price volatility.It is found that Modigliani and Miller's dividend irrelevance theory is valid only for large class of models with asymmetric information (Dybvig and Zender 1991). Empirical studies on dividend policy and share price volatility have proven that there are controversial results as some have identified negative relationship between share price volatility and dividend policy (Baskin, 1989; Hashemijoo et.al, 2012; Alli, et.al 1993; Allen and Rachim, 1996; Ramadan, 2013). In contrast some studies have identified positive 
relationship between share price volatility and dividend policy (Nishat, and Irfan, 2003; Habib, et. al 2012). Some have identified the relationship of two main elements of dividend policy such as dividend yield positive significant effect and payout ratio negative insignificant effect to the share price volatility (Ilaboya and Aggreh 2013; Hussainey et. al 2010). Moreover, it has identified that negative and insignificant effect of dividend yield and positive insignificant effect of payout ratio to share price volatility (Sadiq, et. al, 2013; Zakaria, et. al, 2012; Profilet,et. al, 2013).

Furthermore, this study would be massively significant in various ways to managers and directors, policy makers and stakeholders which will provide more reliable scientific measure and perspective for describing and evaluating the impact of dividend policy on share price volatility for achieving the ultimate goal of maximizing the shareholders wealth.Policy makers like government agencies will be facilitated through invaluable insights while other stakeholders like potential investors, shareholders would be provided with essential information which allows them to provide useful suggestions to the improvement of investing in listed companies in Sri Lanka.Agreeing to the figure 1- All Share Price Index during 2014 to beginning of 2018 of Colombo Stock Exchange (CSE) has indicated huge fluctuations in share prices at observed time period.

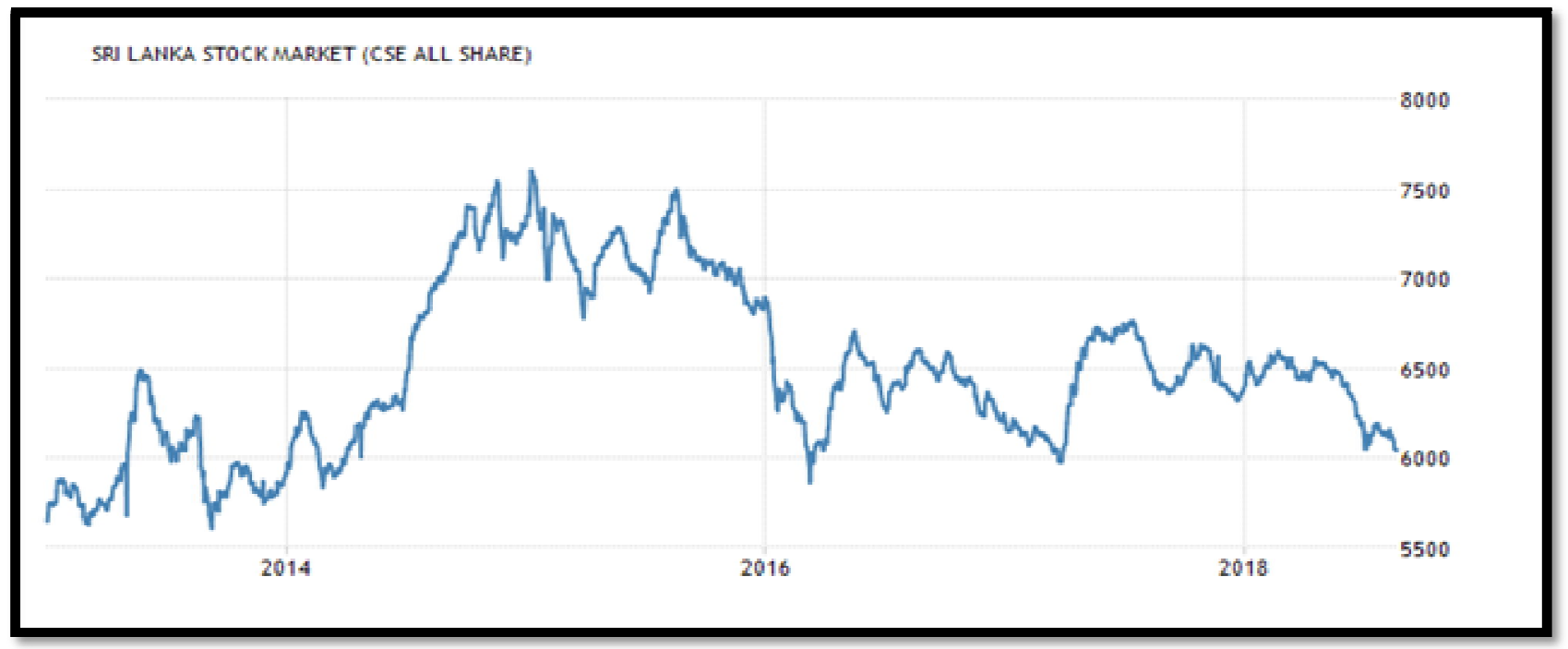

Figure 1: All Share Price Index (ASPI)

Source: Www.Cse.Lk

Therefore, it would be more important to precise the major contributing factors of dividend policy when determining the share price volatility in Sri Lanka. In addition to that there are many studies which have been taken place in global context that quite parallel on current study. But its results may not absolutely applicable for the Sri Lankan context on account of the changes in financial environment in each country inherited with its nature. Owing tothese contradictions of studies in local and global context, it is identified that there is a question to be addressed as "Is there any impact of Dividend Policy on Share Price Volatility in Sri Lanka?" which also would be a great indicator of the current financial situations of Sri Lanka. The main objective of this study is to find out the relationship between dividend policy and share price volatility in Sri Lankan context to recognize the significant financial fluctuations over the selected period.

\section{Literature Review}

\subsection{Dividend Irrelevance Theory}

If a company earns money from day to day operations, that money belongs to shareholders. It should not matter whether a company keeps money and invests it or returns the money to shareholders. It is also possible to show that it should make little difference to investors whether dividends are paid or not as investors they can reproduce the cash flows of different dividend policies. When a company earn more the share price will be increased by the company's stronger cash position. The shareholders of the company can offset that by selling a few shares. These arguments for dividend irrelevance are closely related to the Modigliani-Miller arguments for capital structure irrelevance. Miller and Modigliani (1961) proposed that dividend policy is irrelevant to the shareholder. Under this irrelevance theory, firms that pay more dividends offer less stock price appreciation that would benefit stock owners who could choose to profit from selling the stock. However, the total return from both dividends and capital gains to stockholders should be the same. If dividends are too small, a stockholder can simply choose to sell some portion of his stock. Therefore, if there are no tax advantages or disadvantages involved with these two options, stockholders would ultimately be indifferent between returns from dividends or returns from capital gains.

\subsection{Bird in Hand Theory}

Gordon (1963) and Lintner (1962) with bird in hand theory stated that dividends are relevant to determining the value of the firm. Most common stock valuation model developed by Gordon, explained that the determinants of the value of a firm's cost of equity financing are the dividends that the firm is expected to pay to perpetuity, the expected annual growth rate of dividends and the firm's current stock price. The dividend yield and the future growth of the dividends 
provide the total return to the equity investor. This model confirmed that dividend yield is more important as a measure of total return to the equity investor than the future growth rate of the dividends.

\subsection{Agency Theory}

Under the dividend irrelevance theory, the assumption of perfect capital market implies that there is no any conflict of interests between managers and shareholders. But in practical world this assumption is questionable where the owners of the firm are distinct from its management at large. In these cases, managers are always imperfect agents of shareholders and managers' interests are not necessarily the same as shareholders' interests, and therefore they do not always act in the best interest of the shareholders. Due to this reason shareholders incur costs associated with monitoring managerial behavior which means as agency cost and this agency costs are an implicit cost resulting from the potential conflict of interest among shareholders and corporate managers. The payment of dividends might serve to align the interests and mitigate the agency problems between managers and shareholders by reducing the discretionary available funds.

\subsection{Dividend Policy}

The dividend policy determines the firm policy on distribution of its earnings whether as retained earnings; for reinvesting in new projects and the amount of dividend payments (Allen and Rachim, 1996). Olowe and Moyosore (2010) investigated on the determinants of dividend payout in Nigerian banking industry with secondary data from 2006 to 2008. With the pooled regression technique, the study used profitability, liquidity, corporate tax, revenue growth, market-tobook value ratio, loan-deposit ratio, credit risk ratio, capital adequacy ratio, activity mix, size, cost-income ratio, market power and debt to equity ratio as independent variables while payout policy as the dependent variable. The results of this study outlined that profitability, liquidity, size and activity mix are statistically significant factors which positively influence dividend payout. It also showed that revenue growth, debt-equity ratio, retained earnings, loan-deposit ratio and loan-loss provision negatively influence dividend policy while capital adequacy is inconclusive in its nature.

Mehta (2012), was conducted a study on determinants of dividend policy with the purpose of developing determinants of dividend policy in United Arab Emirates listed companies for five-year time period from 2005 to 2009. Secondary data which have been collected to conduct the study were analyzed by using correlation and multiple regression techniques with the set of independent variables namely profitability, risk, liquidity, size and leverage while dividend payout used as the dependent variable. Finally, the study concluded that the profitability and size seem to be most important considerations of dividend payout decisions by United Arab Emirates listed companies

When identifying the determinants of dividend policy, the study of Badu (2013) conducted his study on listed financial institutions in Ghana from 2005 to 2009 with cross-sectional and time series data. The study used profitability, growth firm age, collateral capacity, leverage, liquidity, cash flow as independent variables while dividend payout strategy as dependent variable. According to regression analysis results, it has established statistically significant and positive relationship between age and liquidity. Moreover, the study established statistically insignificant relationship between profitability, collateral capacity and dividend payment.

\subsection{Share Price Volatility}

In simply variance of the rate of return on share prices becomes share price volatility and traditionally it estimated using closing prices only. It is shown that the use of extreme values (the high and low prices) provides a far superior estimate (Parkinson, 1980). As cited in Guo (2002), stock price volatility is the systematic risk faced by the shareholders in a firm. If the volatility is high, the short run gain or loss goes to higher. If a stock is named as volatile, the price of it would highly vary over time and it is difficult to say in certainty what its future price will be. Investors are always like to face less risk while the less risk is better for the investment. In other words, the lesser the volatility of a given stock, the greater its desirability (Hussainey, 2010). The linkage between the dividend policy of corporations and the volatility of their stock prices has been explored at different times by different scholars (Allen and Rachim, 1996; Baskin, 1989).

\subsection{Dividend Policy and Share Price Volatility under Relevance Theory}

Allen and Rachim (1996) determined relationship between stock price volatility and dividend policy with the purpose of establishing a relationship between dividend policy and share price volatility. Cross sectional regression analysis, correlation analysis and descriptive analysis were used to analyze data from 173 Australian listed companies. The research period was 14 years (1972-1985) and main source of data were secondary data. The study used dividend yield, earning volatility, payout ratio, size, leverage, growth in assets as independent variables and dimensions of dividend policy while share price volatility used as the dependent variable. The results elaborated that dividend yield is correlated with stock price volatility and consistent with expectations, it was evidenced that significant positive correlations between stock price volatility and earnings volatility and leverage, plus a significant negative correlation with the payout ratio.

The study of Hussainey (2010) established a relationship between dividend policy and share price volatility with focus of United Kingdom Capital Market to identify whether the dividend policy has any relationship with stock price movement. Descriptive analysis, correlation analysis and a multiple regression method were used to analyze all publicly quoted companies in the United Kingdom for the research period from 1998 to 2007by secondary data. Share price volatility considered to be the dependent variable and dividend yield, earning volatility, payout ratio, size, debt, growth in assets comprised in independent variables as the dimensions of dividend policy. The regression results of the study found that 
there was a positive relationship between dividend yield and share price volatility and a negative relationship between dividend payout ratio and share price volatility in UK public quoted companies.

Ramadan (2013) clarified the association between dividend policy and stock prices for the Jordanian industrial firms listed at Amman Stock Exchange with the aim of no firm theory or existing model to clarify how dividend policy affect the market value of the company's shares. Descriptive analysis, correlation analysis and a multiple least square regression method were used to analyze data from 77 listed industrial firms. The research period is 11 years (2000-2011) and data were gathered using secondary sources. The study used dividend yield, earning volatility, payout ratio, size, longterm debt, growth in assets as independent variables and dimensions of dividend policy and share price volatility used as the dependent variable. This study concluded significant negative effect of the two components of the dividend policy on the share price volatility in Jordanian industrial firms.

\subsection{Dividend Policy and Share Price Volatility under Irrelevance Theory}

Nishat (2003) identified the role of dividend policy measures to assess the pattern of relationship during prereform (1981-1990) and reform (1991-2000) periods with the purpose of exploring the role of dividend yield and payout ratio impact on share prices. Least squares regression analysis, descriptive analysis and correlation analysis were used to analyze data from 160 listed companies for 20 years from 1981 to 2000 with the secondary data. The study consisted with dividend yield, earning volatility, payout ratio, size, debt, growth in assets as independent variables and share price volatility as dependent variable. The findings of this study revealed that dividend yield and payout ratio have significant impact on the share price volatility while relationship is not reduced much even after controlling for the above-mentioned factors and it suggested that dividend policy affect stock price volatility.

Ilaboya and Aggreh(2013) examined the impact of dividend policy on share price volatility in Nigeria based on the arguments of theories as divided policy has no effect on stock prices (Irrelevance Theory). Descriptive analysis, Step Wise Regression Test and correlation analysis were used to analyze the data of 26 firms in Nigeria from 2004 to 2011. Dividend yield, earning volatility, payout ratio, size, long-term debt, growth in assets considered as a proxy of independent variables on dividend policy while share price volatility would be the dependent variable. This study accomplished dividend yield appeared positive and significant relationship and payout ratio appeared negative and insignificant on Nigerian firms. The study highlighted that the component of debt appeared to impact positively on stock price volatility as well.

In Asian context the study of Sadiq (2013), explored relative relationship between dividend policy and price volatility in case of Pakistan market. Descriptive analysis, a cross-sectional multiple least square regression method was used to analyze data from 35 companies for the time period of 2001-2011. The independent variables comprised with dividend yield, earning volatility, payout ratio, size, earnings per share, growth in assets as dimensions of dividend policy while share price volatility used as the dependent variable. This study established negative relationship between price volatility and dividend yield but this relationship is not statistically significant in all the partial regression models. It also found positive insignificant relationship between size of firms and price volatility of stocks plus positive and statistically significant relationship between growth of firms and price volatility. Earnings per share and price volatility of stocks emphasized a negative but statistically insignificant relationship though price volatility and earning volatility of firms have no relationship.

\subsection{Impact of Dividend Yield and Firm Size on Share Price Volatility}

Hashemijoo (2012) examined the relationship between dividend policies on share price volatility in Malaysian stock market to establish a consensus among researchers about the impact of dividend policy on share price. More descriptively dividend yield, earning volatility, payout ratio, size, long term debt, growth in assets included in independent variables and share price volatility used as the dependent variable. Descriptive analysis, cross-sectional multiple least square regression methods were used to analyze the data which were in secondary mode from 2005 to 2010 . The scholar of this study found that there is a significant negative relationship between share price volatility with two main measurements of dividend policy though dividend yield and size induce the greatest influence on share price volatility among predictor variables.

With the aim of launching a firm theory or existing model to clarify how dividend policy affect the market value of company's shares, Profilet (2013) conducted a study on understanding the true correlation between a company's dividend policy and stock price volatility. In this study share price volatility represented the dependent variable and dividend yield, earning volatility, payout ratio, size, leverage, growth in assets as independent variables and dimensions of dividend policy. Collected data from 599 firms for 2010, 2011 and 2012 were analyzed by using ordinary least squares multiple regression analysis and correlation analysis. The ultimate results of this study concluded that dividend yield and leverage, size, growthhas been negatively related to stock's price volatility thus payout ratio and stock price volatility has been positively related with each other.

\subsection{Impact of Payout Ratio and Dividend Yield on Share Price Volatility}

In respect of construction sector, Zakaria (2012) examined the impact of the dividend yield and dividend payout ratio on share price of construction and material companies listed in Bursar Malaysia and other determinants share price volatility. The study lined up dividend yield, earning volatility, payout ratio, size, leverage, growth in assets contrary to share price volatility. Descriptive analysis, multiple least square regression method was used to analyze data from 77 companies listed in Malaysia. It generalized a significant positive relationship between dividend payout ratio of a firm and share price volatility andinsignificantly negative movement of stock prices on dividend yield. 


\section{Methodology}

The investigation of this study is highly interacted with finance aspects of the country as dividend policy and share price volatility in Sri Lanka. To complete this study in meaningful way, the variables have been selected on the basis of literature by different scholars in different geographical areas. Dividend payout ratio and dividend yield reflects the dividend policy as independent variable while share price volatility will be the dependent variables with three control variables namely firm size, growth in assets and debt.

Hypothesis: Following the studies of Ramadan (2013), Hussainey (2010), Ilaboya and Aggreh(2013)and many others assumed that there is a significant relationship between dividend policy and share price volatility in Sri Lanka. According to this study the hypotheses are;

- $\quad \mathrm{H} 1=$ There is significant a relationship between dividend payout ratio and share price volatility

- $\quad \mathrm{H} 2=$ There is a significant relationship between dividend yield and share price volatility

\subsection{Data Collection and Sampling}

The main data sources of this study would be the annual reports of selected listed companies in Colombo Stock Exchange. Therefore, the data will be in secondary data as collected through publications.The population of this study was all listed companies comprised in all 20 sectors in CSE for the date of 1st of March 2009 onwards. CSE includes 297 listed companies for the date of 30st June 2017. As it was practically impossible to take all the listed companies in CSE, the sample space was filtered based on market capitalization value of the companies from highest to lowest respectively for the date of 31st December 2017 and selected 30 companies for the time period of four years from 2014 to 2017 through stratified sampling technique.

\subsection{Data Analysis}

Following analysis tools were used to test the hypotheses of this study such as Descriptive Statistic, Correlation, Coefficients while Regression Analysis as the main tool to draw a better conclusion. To examine the effect of dividend policy on share price volatility in Sri Lanka, the applicable regression model is shown as follows:

$\mathrm{SPV}=\beta 0+\beta 1 \mathrm{DY}+\beta 2 \mathrm{DPR}+\beta 3 \mathrm{FSZ}+\beta 4 \mathrm{GAS}+\beta 5 \mathrm{DEB}+\varepsilon$

Where:

$\beta \quad=$ Shows the constant affecting dividend policy on share price volatility

SPV = Share Price Volatility

DY $\quad=$ Dividend Yield

DPR =Dividend Payout Ratio

FSZ $\quad=$ Firm Size

GAS $\quad=$ Growth in Assets

DEB $=$ Debt

$\varepsilon \quad=$ Error Term

Under regression analysis it developed mathematical model to predict a dependent variable by two or more independent variables or in which at least one predictor is non-linear.

\section{Data Analysis}

The study has been designed with the analysis tools of Descriptive Statistic, Correlation, Coefficients and Regression Analysis to test whether the created hypothesis which have been used to answer the research questions can be accepted or not.

\begin{tabular}{|c|c|c|c|c|}
\hline & Minimum & Maximum & Mean & Std. Deviation \\
\hline DY & 0.0000 & 0.0706 & 0.026841 & 0.0179343 \\
\hline DPR & 0.0000 & 4.1667 & 0.391410 & 0.4637310 \\
\hline FSZ & 22.1943 & 27.4044 & 24.750552 & 1.1662376 \\
\hline GAS & -0.1819 & 1.0036 & 0.186887 & 0.1519719 \\
\hline DEB & 0.0602 & 0.9284 & 0.557974 & 0.2358542 \\
\hline SPV & 0.0143 & 0.8158 & 0.208454 & 0.1589414 \\
\hline
\end{tabular}

Table 1: Descriptive Statistic

Source: Research Data

The descriptive analysis Table 1 is showing the descriptive statistics of all the variables which consisting with the Mean, Standard deviation and Minimum and Maximum values of the data set. The mean values of variables are indicating the average values consisting in the data set while standard deviation values imply whether those mean values are concentrated around the mean or scattered far and wide. As it pointed out all the figures in this study; dividend yield, dividend payout ratio, growth in assets, debt and share price volatility seemed to be concentrated around its mean values while firm size scattered widely respectively. 


\begin{tabular}{|c|c|c|c|c|c|c|}
\hline & DY & DPR & FSZ & GAS & DEB & SPV \\
\hline DY & 1 & & & & & \\
\hline DPR & $.297^{* *}$ & 1 & & & & \\
\hline FSZ & .030 & -.181 & 1 & & & \\
\hline GAS & $-.198^{*}$ & -.047 & .164 & 1 & & \\
\hline DEB & $.245^{*}$ & .131 & $.556^{* *}$ & .057 & 1 & \\
\hline SPV & $-.217^{*}$ & .016 & $-.262^{* *}$ & $.431^{* *}$ & -.015 & 1 \\
\hline
\end{tabular}

Table 2: Correlations

**. Correlation Is Significant at the 0.01 Level (2-Tailed)

Source: Research Data

Table 2 shows the correlation as share price volatility negatively and significantly correlated with dividend yield while positively and insignificantly correlated with dividend payout ratio. at the view of control variable, the firm size and debt are negatively correlated with share price volatility and firm size has significant relationship whereas debt is insignificant. There is a positive significant relationship among share price volatility and growth in assets

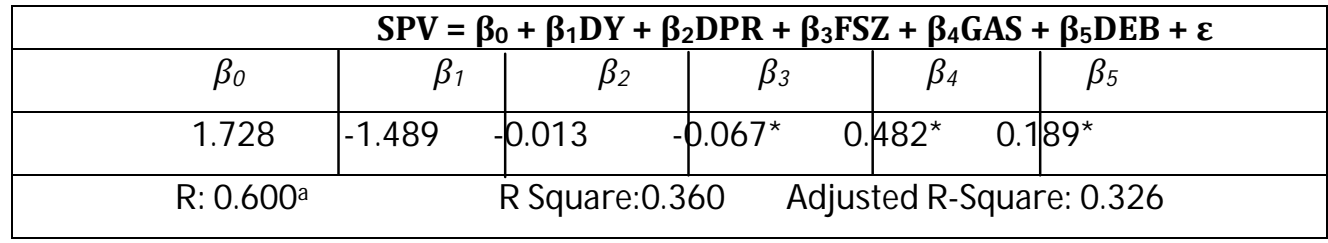

Table 3: Results of Regression Analysis

*. Significant at $5 \%$

Source: Research Data

The above table 3 is demonstrating the results of the multiple regression analysis which consisting the values of unstandardized coefficients, R Square and Adjusted R Square of the model for the purpose of exploring relationship between the dependent and independent variable. $R$ represents that the correlation between the observed and predicted values of dependent variable and at $\mathrm{R}$ Square value it implies that the $36 \%$ of variation on share price volatility can be explained by the independent variables in this study namely dividend yield, dividend payout ratio, debt, growth in assets and firm size.

\section{Results and Discussion}

According to the findings of many other scholars in this field, it has been revealed that the dividend policy highly affected to the fluctuations in share prices of a certain country and following studies can be considered as comparable investigations with current study.

The study of Zakaria, (2012) which is align with the current study has investigated the relationship between dividend yield and share price volatility by using the data of 77 companies and found that there was an insignificant negative relationship between dividend yield and share price volatility through the results of descriptive analysis, correlation and multiple least square regression methods. Sadiq (2013) explored relative relationship between dividend policy and share price volatility in case of Pakistani market and found both positive and negative relationships between dividend policy and price volatility. This study established negative insignificant relationship between dividend yield and share price volatility and positive insignificant relationship between size of the firm and share price volatility; confirmed the results of current study in advance. According to Hussainey (2010), there was a negative relationship between dividend payout ratio and share price volatility and positive relationship between dividend yield and price volatility. Furthermore, Ilaboya and Aggreh (2013) examined the impact of dividend policy on share price volatility in Nigeria and found that there was a relationship among payout ratio and price volatility which was insignificant while relationship between dividend yield and price volatility was significant.

Accordingly, most of studies have concluded that the relationship between dividend policy and share price volatility exhibits a negative and insignificant relationship of those countries which also statistically proved at current study with Sri Lankan context.

\section{Conclusion}

As the main objective of this study, it focused to identify the relationship between dividend policy and share price volatility in Sri Lanka by using listed companies at Colombo Stock Exchange. Dividend yield, dividend payout ratio, firm size, growth in assets and debt have been used as the dimensions of dividend policy to examine the relationship between share price volatility for a period of four years from 2014 to 2017. The data collected from 30 public listed companies in Sri Lanka based on the market capitalization value were analyzed by using descriptive statistics, correlation analysis and regression analysis. According to those measurements dividend yield coefficients and dividend payout ratio coefficients were used as independent measurements and firm size coefficients, growth in assets coefficients and debt coefficients were used as control measurements to investigate the impact to share price volatility. 
The findings clearly revealed that in what extent the independent variables dividend yield and dividend payout ratio on dependent variable of share price volatility have been affected in the considered time period. When consider about each independent variable in relation with dependent variable, there is a negative and insignificant relationship between dividend payout ratio and share price volatility. That means when the firms increase the dividend payout ratio affect to decrease in share price volatility insignificantly. Besides that, dividend yield also negatively and insignificantly affect to share price volatility. It emphasized that when there is an increment in dividend yield, it would affect on decrement of share price volatility insignificantly. Finally, it can be concluded that there is a negative insignificant relationship between dividend payout ratio as well as dividend yield and share price volatility.

The relationship between dividend policy and share price volatility is quite significant to investors, policy makers, portfolio managers and researchers who are interested in capital market on decision making activities with the perspective of investment risk. Therefore, the managers should be knowledgeable enough to make decisions on valuation of shares, investment and dividend decisions in wide manner. To expand future studies, it should be focused on expanding the sample size by focusing on different sectors in Colombo Stock Exchange to find out the different aspects of share price volatilities on various dividend policies. It can be incorporated with new conceptual framework to measure the dimensions in advance as well. Furthermore, this research area can be integrated with emerging markets more over than Sri Lanka such as Malaysia, Nigeria and Pakistan to identifying or establishing relationship between share price volatility and dividend policy in global perspective. Despite of dividend yield and dividend payout ratio, other determinants namely technical factors which are the mix of external conditions that alter the supply of and demand for a firm's stock and economic growth which indirectly contributes to earnings growthcan be used to identify the degree of impact on share prices volatility as different concepts to expand this studies scope into wide range.

\section{References}

i. Ahmed, H., \& Javid, A. (2009). The Determinants of Dividend Policy in Pakistan. International Research Journal of Finance and Economics, 29.

ii. Alli, K., Khan, A., \&Ramirez, G. (1993). Determinants of dividend policy: A Factorial Analysis. Finance Rev, 28, 523547.

iii. Allen, D.E \& Rachim, V.S. (1996). Dividend Policy and Stock Price Volatility: Australian Evidence. Applied Financial Economics, pp175-188.

iv. Amidu, M., \& Abor, J. (2006). Determinants of Dividend Payout Ratios in Gahana. The Journal of Risk Finance, 7:136-45.

v. Badu, E.A. (2013). Determinants of Dividend Payout Policy of listed Financial Institutions in Ghana. Research Journal of Finance and Accounting, Vol.4, No.7.

vi. Baker, H. K., \& Powell, G. E. (2000). Determinants of Corporate Dividend Policy: A Survey of NYSE firms. 9:29-40.

vii. Baker, H. K., Farrelly, G. E., \& Edelman, R. B. (1985). A Survey of Management Views on Dividend Policy. Financial Management, 14:1007-34.

viii. Baskin, J. (1989). Dividend Policy and Volatility of Common Stocks. The Journal of Portfolio Management, Vol.15.3, pp19-25.

ix. Dybving, P.H., \& Zender, J.F. (1991). Capital Structure and Dividend Irrelevance with Asymmetric Information. Vol.4, No.1, pp. 201-219.

x. Gill, A., Biger, N., \& Tibrewala, R. (2010). Determinants of Dividend Payout Ratio: Evidence from United States. The Open Business Journal, Vol: 3, 8-14.

xi. Gordon, M.J. (1963). Dividends, Earnings, and Stock Prices. The Review of Economics and Statistics, Vol. 41, No. 2, May, 1959, pp. 99-105.

xii. Gunasekarage, A., \& Colombage, S.R.N. (2002). The Behavior of Share Prices in Emerging Markets: Evidence from the Colombo Stock Exchange. Journal of Management Science, Vol. 1, pp. 194-116.

xiii. Guo, H. (2002). Stock Market Returns, Volatility, and Future Output. Research Journal of Finance and Accounting, Vol.3, No.2.

xiv. Habib, Y., Kiani, Z.I. \& Khan, M.A. (2012). Dividend Policy and Share Price Volatility: Evidence from Pakistan. Global Journal of Management and Business Research, Vol. 12, March 2012.

xv. Hashemijoo, M., Ardekani, A.M., \&Younesi, N. (2012). The Impact of Dividend Policy on Share Price Volatility in the Malaysian Stock Market. Journal of Business Studies Quarterly. Vol. 4, No. 1, pp. 111-129.

xvi. Hussainey, K., Oscar, C., \&Chijoke, A.M. (2010). Dividend Policy and Share Price Volatility: UK Evidence. Journal of Risk Finance. Vol. 4, 2010.

xvii. Ilaboya O.J and Aggreh M. (2013). Dividend Policy and Share Price Volatility. J. Asian Dev. Stud Vol. 2, Issue 2, June 2013.

xviii. Linter, J. (1962). Distribution of incomes of corporations among dividends, retained earnings and taxes. American Economic Review, 46: 97-113.

xix. Mehta, A. (2012). An Empirical Analysis of Determinants of Dividend Policy - Evidence from the UAE Companies. Global Review of Accounting and Finance.

xx. Miller, M. H., \& Modigliani, F. (1961). Dividend Policy, Growth and Valuation of Shares. The Journal of Business, 34:411-433.

xxi. Nishat, M. \& Irfan, C. (2003). Dividend Policy and Stock Price Volatility in Pakistan. 11th Pacific Business Finance, Economics and Accounting Conference. 
xxii. Olowe,R.A., \&Moyosore, S.L. (2010). Determinants of Dividend Payout in the Nigerian Banking Industry. Global Review of Accounting and Finance, Vol. 3. No. 1.

xxiii. Parkinson, M. (1980). The Extreme Value Method for Estimating the Variance of the Rate of Return. The Journal of Business, Vol. 53, No. 1, January 1980, pp. 61-65.

xxiv. Porta, R. L., Lopez, D. S., Shleifer, A., \& Vishny, R. W. (2000). Agency Problems and Dividend Policies around the World. The Journal of Finance, 1-33.

xxv. Profilet, Kyle A. \& Bacon, Frank W. (2013). Dividend policy and stock price volatility in the U.S. Equity Capital Market. ASBBS Annual Conference: Las Vegas, Vol.20, February 2013.

xxvi. Ramadan, I.Z. (2013). Dividend Policy and Price Volatility: Empirical Evidence from Jordan. International Journal of Academic Research in Accounting, Finance and Management Sciences, Vol. 3, No.2, April 2013, pp. 15-22.

xxvii. Rashid, A. \& Rahman, A.Z.M.A. (2010). Dividend Policy and Stock Price Volatility: Evidence from Bangladesh. Applied Business and Economics.

xxviii. Retrieved from: http:// www.pitt.edu

xxix. Retrieved from: http:/ / www.cse.lk/ data

xxx. Sadiq, M., Ahmad, S., Anjum, M.J., Suliman, M., Abrar, S.U. \& Khan, S.U.R. (2013). Stock Price Volatility in Relation to Dividend Policy;A Case Study of Karachi Stock Market. Middle-East Journal of Scientific Research Vol. 13 (3), pp. 426-431.

xxxi. Zakaria, Zuriawati, Joriah Muhammad, \& Abdul Hadi Zulkifli. (2012). The impact of dividend policy on the share price volatility: Malaysian construction and material companies. International Journal of Economics and Management Sciences, 2.5 (2012): 1-8.

xxxii. Zameer, H., Rasool, S., Iqbal, S., \& Arshad, U. (2013). Determinants of Dividend policy: A case of Banking Sector in Pakistan. Middle-East Journal of Scientific Research, 18(3):410-424. 